70 巻 691 号 (2004-3)

\title{
マニピュレータがもつ柔軟ツールの位置とカのハイブリッド制御*
}

\author{
黄 \\ 健*1, 藤 堂 勇 雄 $* 2$
}

\section{Position and Force Hybrid Control of a Flexible Tool Held by a Manipulator Hand}

\author{
Jian HUANG $^{* 3}$ and Isao TODO \\ ${ }^{* 3}$ Department of Mechanical Engineering, Graduate School of Engineering, Yokohama National University, \\ 79-5 Tokiwadai, Hodogaya-ku, Yokohama-shi, Kanagawa, 240-8501 Japan
}

\begin{abstract}
A flexible tool held by the end joint of a robot will be deformed when the robot is used to complete a contact task. Without establishing a deformation model of the flexible tool, the end position of the flexible tool can not be obtained from computing robot kinematics. In this paper, a position and force hybrid control method using the visual information has been proposed for a $6 \mathrm{DOF}$ robot to complete a contact task. To detect the end position of the flexible tool, two CCD cameras are used and a real time image processing algorithm is developed. An advantage of the proposed method is that establishing a deformation model of the flexible tool is not necessary. An online learning neural network is also applied to a position/force hybrid control system to decrease tracing error of position. Using the proposed method, a flexible tool held by a $6 \mathrm{DOF}$ robot hand was used in experiments of tracing a given curve with a specified force. The experiments have been made successfully and the results demonstrate the effectiveness of the proposed method.
\end{abstract}

Key Words: Mechatronics and Robotics, Digital Control, Robot, Image Processing, Learning, Neural Network, Sensor Fusion, Flexible Tool, Deformable Tool

\section{1. まえがき}

医療福祉ロボットや生活支援ロボットの作業対象の 多くは柔軟物体であるため，ロボットによる柔軟物体 の操作に関する研究が多く行われてきだ!.これらの 研究としては，管状や電線状のような細長い柔軟物体 の操作(の)，柔軟曲面での倣い(の，布のマニピュレーシ ヨンの，柔軟物体のモデリング，画像情報を用いた 柔軟物体の操作 ${ }^{929}$ ，視覚情報と力覚情報のセンサフ ユージョンによる変形物体の操作闪などが報告された。

これらの研究は，柔軟な作業対象を扱うロボットの 制御アルゴリズム，あるいは作業の実現方法を導くも のがほとんどであった.一方, 医療現場，生活環境に おいて壊れやすい判体の対象に対してロボットの手先 に柔軟ツールを取り付け，ツール先端の位置と力を制 御する必要がしばしばある. しかしながら、ツールの 材質によって変形モデルを算出できない場合には，運 動学に基づくこれまでの手法をツール先端の位置制御 に適用することは困難である.

* 原稿受付 2003 年 6 月 16 日.

*1 正員, 横浜国立大学大学院工学研究院 (-240-8501 横浜市 保土ケ谷区常盤台 79-5).

*2 正員, フェロー, 横浜国立大学大学院工学研究院.

E-mail : huang@ post.me.ynu.ac.jp
柔軟ツールをロボットの手先に取り付けてツール先 端に接触作業を行わせる場合, 接触によってツールに 変形が生じる. ツールの変形モデルを作成し変形を解 析しないかぎり, ロボットの運動学からツール先端の 位置を算出することはできない，本論文では，立体視 情報を用いてツールの先端位置を高速で検出すること によって構成する位置と力のハイブリッド制御手法を 提案する. また, 追従精度を向上させるため, ニュー ラルネットワークによるオンライン学習を用いた. 提 案した手法を用いて柔軟ツールの先端を与えられた平 面曲線軌道に押し付けながら追従させる実験を行い， その効果を確かめた. この手法では, 柔軟ツールの変 形モデルを作成することによって変形を解析する必要 はないという利点がある.

\section{2. 作莱と作菜システムの構成}

本論文で用いる作業システムは，可搬式汎用知能ア 一ム (PA-10, 三菱重工) 1 台, カ覚センサ (F/T 10/100, ビー・エル・オートテック） 1 台, 小型 CCD カメラ (XC-EI50, ソニー) 2 台とパーソナル コンピュータ (Dimension XPS B733r, DELL社) 1台 から構成されている. その構成を図 1 に示す．作業中 に生じる接触力の情報を検出するため，力覚センサを 


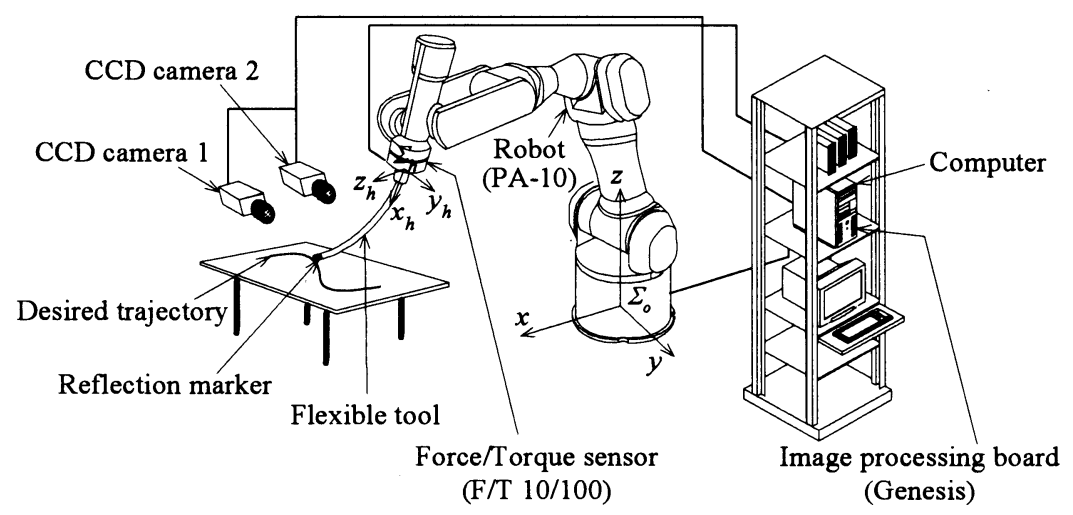

Fig. 1 Setup of a robot control system with a flexible tool held by the hand of a robot.

ロボットの手先に装着する.

本論文では，長さ $0.3 \mathrm{~m}$ の塩化ビニール製チューブ を柔軟ツールとしてロボットの手先に取り付ける. ツ ールの先端位置を画像処理によって検出するため, カ メラ 2 台の前にリング型赤外照射器 (IRDR-110, 日 進電子工業) を取り付け，チューブの先端に反射マー カーを貼り付ける. また, 図 1 に示すロボットアーム は7自由度を有するが, 本論文では, アームの冗長自 由度を固定し，6自由度アームとして用いる.

図 1 に示すように, 2 台のCCDカメラが, $x$ 軸の 正方向に約 $0.66 \mathrm{~m}$ と $1.04 \mathrm{~m}, y$ 軸の負方向に約 $0.55 \mathrm{~m}$, $0.45 \mathrm{~m}, z$ 軸の正方向に約 $0.65 \mathrm{~m}$ の場所に置かれてい る. 2 台のカメラの距離は $0.45 \mathrm{~m}$ である. 2 台のカメ ラから構成される立体視画像システムによって 3 次元 空間におけるツールの先端位置を検出し, ロボットの 制御に用いる. また， $x$ 軸の正方向に約 $0.7 \mathrm{~m}$ の場所 に作業台を置く，作業は，柔軟ツールの先端を押し 付けながら作業台に与えられている曲線軌道に追従さ せることである. 接触によっでールに変形が生じる ため, ロボットの運動学功ツール先端の位置を算出 することはできない．

\section{3. 画像処理と補間}

本論文に用いた 2 台のCCDカメラは毎秒 30 フレ ームの画像を出力する. パーソナルコンピュータには 画像入力・処理ボード(GENESIS GEN/F/64/8 /STD, Matrox 社)が取り付けられており，このボード上に DSP (Digital signal processor) C80 が装着されている.

$3 \cdot 1$ 画像のパラレル処理一般に, 画像情報を見 落とさず最大限に利用するためには，画像を取り込み ながら処理する手法 (以下，「画像の実時間処理法」 と呼ぶ) が望ましい. したがって, 3 次元空間におけ る柔軟ツールの先端位置を実時間で検出するため, 画
像情報をパラレルに処理する必要がある.

一方，DSPをもつ画像処理ボード GENESIS はダブ ルバファリング(Double buffering) という高速画像処理 機能を有する. ダブルバファリング機能とは，画像の 入力と処理が別々に確保されたデータバッファで同時 に行われることである. この機能を用いて画像の入力

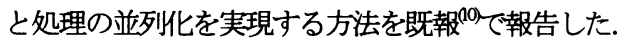

本論文では，この手法を用いるため，連続的に出力さ れている画像を見落とすことなくスムーズに処理する ことができる. また, 2 台のカメラを用いて立体視画 像システムを構成し, ツールの先端位置を観測する.

3.2 画像枯報の補间 本論文では, ロボットの 制御サンプリング周期を $T(=5 \mathrm{~ms})$, 画像入力・処理の サンプリング周期を $T_{d}(=33.33 \mathrm{~ms})$ とする. 一般に, 画 像データを実時間で処理する場合, $T_{c}$ は $T$ の整数倍 にならない. ロボット制御と画像処理のタイムチャー 卜を図 2 に示す．ロボットを制御する際には， $T_{c}$ は $T$ より長いため, $T_{c}$ ごとに画像処理によって得られた目 標位置 $\boldsymbol{p}_{t}^{c}(n) \in R^{3 \times 1}$ をロボットの制御サンプリング周 期 $T$ ごとに補間する必要がある. ここで, $T_{c}$ と $T$ の

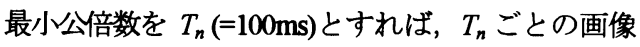
処理の式を考えればよい.

図 2 に示すように, 時刻 $t(n-1) T_{c}$ にて入力され た画像の処理を時刻 $t=k T$ において終了し, 2 台のカ

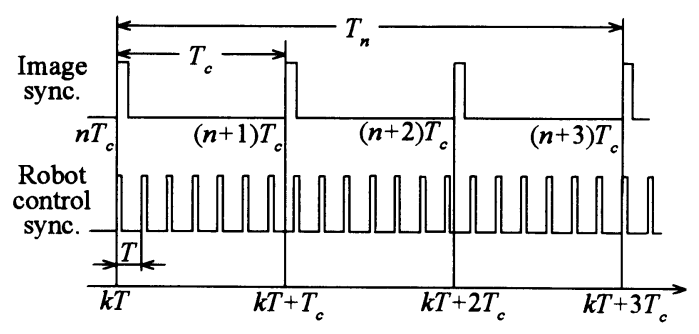

Fig. 2 Time chart of image processing 
メラによって柔軟ツール先端の 3 次元空間位置 $\boldsymbol{p}_{t}^{c}(n-1)$ が得られる. $T_{c}$ ごとに得られた位置情報 $\boldsymbol{p}_{t}^{c}(n-1), \boldsymbol{p}_{t}^{c}(n-2)$ を用いて制御サンプリング周期 $T$ ごとの位置 $\boldsymbol{p}_{t}(k) \in R^{3 \times 1}$ を

$$
\begin{gathered}
\boldsymbol{p}_{t}(k)= \\
\boldsymbol{p}_{t}^{c}(n-1)+\left(k T-(n-1) T_{c}\right) \frac{\boldsymbol{p}_{t}^{c}(n-1)-\boldsymbol{p}_{t}^{c}(n-2)}{T_{c}} \\
\left(n T_{c} \leqq k T<(n+1) T_{c}\right), \\
\boldsymbol{p}_{t}^{c}(n)+\left(k T-n T_{c}\right) \frac{\boldsymbol{p}_{t}^{c}(n)-\boldsymbol{p}_{t}^{c}(n-1)}{T_{c}} \\
\left((n+1) T_{c}<k T<(n+2) T_{c}\right), \\
\boldsymbol{p}_{t}^{c}(n+1)+\left(k T-(n+1) T_{c}\right) \frac{\boldsymbol{p}_{t}^{c}(n+1)-\boldsymbol{p}_{t}^{c}(n)}{T_{c}} \\
\left((n+2) T_{c}<k T<(n+3) T_{c}\right), \\
\cdots \cdots \cdots \cdots \cdots \cdots \cdots \cdots \cdots \cdots,(1) \\
(k=0,1, \cdots \cdots,(n=0,1, \cdots)
\end{gathered}
$$

によって補間する。ただし， $n=0$ のとき， $\boldsymbol{p}_{t}^{c}(-1)=\mathbf{0}, \boldsymbol{p}_{t}^{c}(-2)=\mathbf{0}$ とする.

\section{4. ロボットの目標勃道の生成}

図1に示すように，本論文で取り上げるタスクは， 柔軟ツールの先端を $z$ 軸方向において一定の力 $f_{z d}$ で押 し付けながら与えられた曲線軌道に追従させることで ある. ロボットの目標位置を生成する原理を分かりや すく説明するため, 図 3,4 に示すようにまず $x$ 軸方向 に柔軟ツール先端を移動させる作業を考える.ただし， 本論文での作業は下記の条件で行われるものとする.

(1) 追従軌道は平面上に描かれた曲線とする.

(2) 作業中にツール先端の進行方向（図 3,4 の場合, $x$ 軸方向）と $z$ 軸を含む平面の法線方向の回り（図 3,4 の場合, $y$ 軸回り）にロボット手先の回転姿勢は一定 とする. ただし, 説明便宜のため, 図 3,4ではロボッ トの手先は作業面に垂直と仮定する.

剛体ツールの場合, 押し付け力によるツールの変形 がないため, 運動学の計算て岡体ツールの長さを考慮 すれば，剛体ツールの先端位置はロボットの関節角度 から容易に算出できる. しかしながら, 柔軟ツールの 場合, 押し付け力によってツールの変形が生じるため, 剛体ツールのように運動学によって柔軟ツールの先端 位置を算出できない．

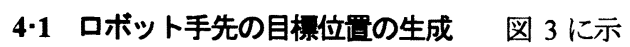
すように, 時刻 $t=k T$ のときロボットの手先を位置 $p_{h}(k)$ から間隔 $d$ だけ先にある目標位置 $\boldsymbol{p}_{h d}(k+1)$ 一移動 させるが, $z$ 軸方向の変動甘によっでール先端は位
置 $\boldsymbol{p}_{t}(k)$ から距離 $d_{1}$ だけ先の位置 $\boldsymbol{p}_{t}(k+1)$ に到達し, 目 標位置 $\boldsymbol{p}_{\mathrm{td}}(k+1)$ には到着できないことが分かる. ロボ ットの手先を 3 次元空間内で移動させるため, 位置情 報 $p_{h d}(k), p_{h}(k)$ は $R^{3 \times 1}$ のベクトルである. 同様に, 柔軟ツール先端の位置情報 $\boldsymbol{p}_{t}(k), \boldsymbol{p}_{t d}(k)$ は， $R^{3 \times 1}$ のべ クトルと定義される.

ツール先端を目標位置 $\boldsymbol{p}_{t d}(k+1)$ に到達させるために は，図4に示すように $z$ 軸方向の変動 $\Delta z$ に合わせてロ ボット手先の位置 $\boldsymbol{p}_{h}(k)$ を距離 $d_{2}$ 先の目標位置 $p_{h d}(k+1)$ に移動させる必要がある.

ここで, ツール先端は $x-y$ 平面を一定の力 $f_{z d}$ で押し 付けているとき, ツール先端とロボット手先との距離 の初期值を $L_{0}$ とする. 時刻 $t=k T$ のとき, $x-y$ 平面に おけるツール先端の目標位置を $\boldsymbol{p}_{t d}(k)=\left[x_{t d}(k), y_{t d}(k)\right.$, $\left.z_{t d}(k)\right]^{T}$ とし, 角度 $\phi$ を直線 $L_{0}$ と $x-y$ 平面となす角度と する. また, ツール先端の進行方向の方向ベクトル $\tilde{\boldsymbol{p}}_{t d}(k) \in R^{3 \times 1}$ は

$$
\tilde{\boldsymbol{p}}_{t d}(k)=\frac{\boldsymbol{p}_{t d}(k+1)-\boldsymbol{p}_{t d}(k)}{d}
$$

で表される. ただし, 距離 $d$ は

$$
d=\sqrt{\left(x_{t d}(k+1)-x_{t d}(k)\right)^{2}+\left(y_{t d}(k+1)-y_{t d}(k)\right)^{2}}
$$

から求まる. また， $x-y$ 平面における直線 $L_{0}$ の投影べ クトル $\Delta p_{L}(k) \in R^{3 \times 1}$ は

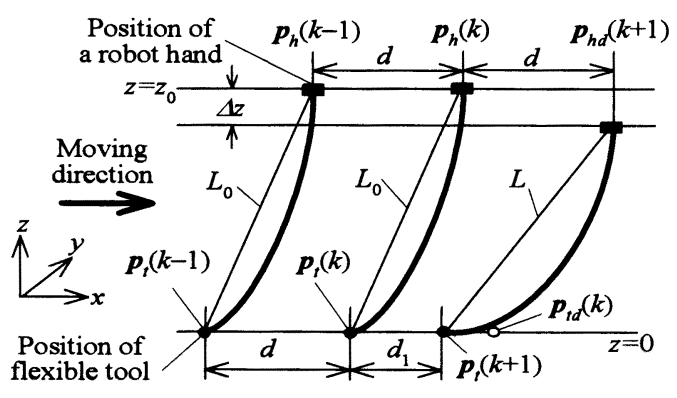

Fig. 3 Moving robot hand forward with a distance $d$

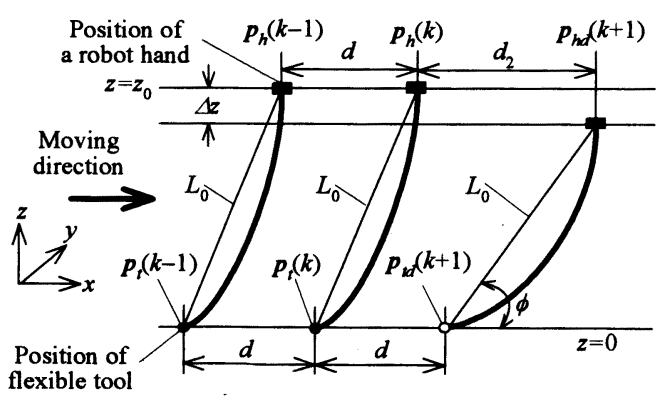

Fig. 4 Moving flexible tool forward with a distance $d$ 


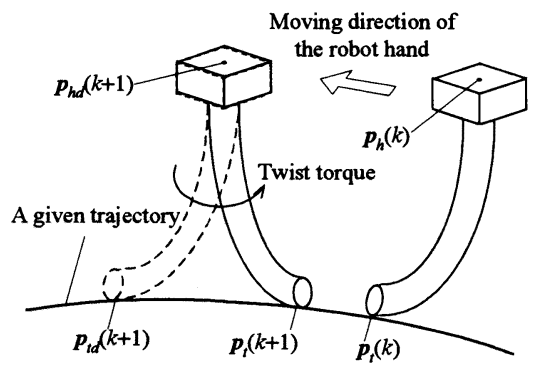

Fig. 5 Rotation of the flexible tool caused by twist torque

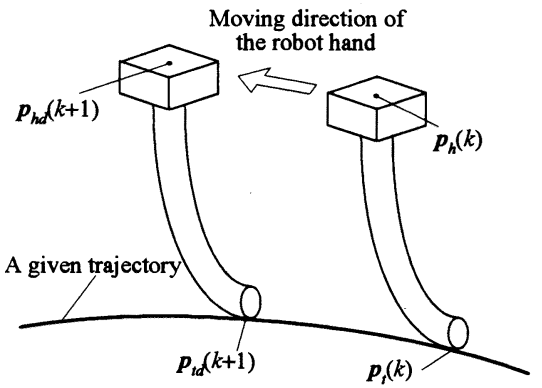

Fig. 6 Avoidance of rotation of the flexible tool caused by twist torque

$\Delta \boldsymbol{p}_{L}(k)=L_{0} \cos \phi \cdot \tilde{\boldsymbol{p}}_{t d}(k)$

で表される. ただし，角度 $\phi を$

$$
\phi=\sin ^{-1}\left(\frac{z_{0}-\Delta z}{L_{0}}\right)
$$

から求める. さらに, 時刻 $t=k T$ におけるツール先端 の追従誤差 $\Delta \boldsymbol{p}_{t}(k)$ を考慮すると， $x-y$ 平面におけるロ ボット手先の目標位置 $\boldsymbol{p}_{h d}^{x y}(k)$ は

$$
\boldsymbol{p}_{h d}^{x y}(k)=\boldsymbol{p}_{\boldsymbol{t} d}(k+1)+\Delta \boldsymbol{p}_{L}(k)+\Delta \boldsymbol{p}_{t}(k) \cdots \cdots \cdot \cdots \cdot \cdots(6)
$$

から算出される.ただし, ツール先端の追従誤差 $\Delta \boldsymbol{p}_{t}(k)$ は $\Delta \boldsymbol{p}_{t}(k)=\boldsymbol{p}_{t d}(k)-\boldsymbol{p}_{t}(k)$ とする. また, 時刻 $t=k T$ におけるロボット手先の目標位置 $p_{h d}(k)$ は

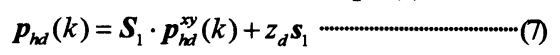

から生成される. ただし, 行列 $S_{1}$, ベクトル $\boldsymbol{s}_{1}$ は

$$
\begin{aligned}
& S_{1}=\operatorname{diag}\left[\begin{array}{lll}
1 & 1 & 0
\end{array}\right] \text {........................................................(8) } \\
& s_{1}=\left[\begin{array}{lll}
0 & 0 & 1
\end{array}\right]^{T}
\end{aligned}
$$

で与えられる. また， $z$ 軸方向に力の制御を行うため, 便宜上 $z_{d}$ は $z_{0}$ とする.

4.2 口ボット手先の目粠姿势の生成 図 1 に示 すように, ベース座標系 $\Sigma_{o}$ におけるロボット手先座 標系 $\Sigma_{h}$ の姿勢は $x-y-z$ 固定角法によって定義される. ここで， $t=k T$ においてロボット手先の姿勢を $a(k)$, $\beta(k), \gamma(k)$ とする. このとき，ロボット手先の目標姿勢 $\boldsymbol{r}_{h d}(k) \in R^{3 \times 1}$ は

$$
\boldsymbol{r}_{h d}(k)=\left[\begin{array}{lll}
\alpha_{d}(k) & \beta_{d}(k) & \gamma_{d}(k)
\end{array}\right]^{T}
$$

で表される. ツール先端の進行方向と $z$ 軸を含む 平面の法線回りにロボット手先の回転がないよう にするため， $\alpha_{d}(k), \beta_{d}(k)$ はそれぞれ一定值 $\alpha_{d} \beta_{d}$ にす る. しかしながら, 図 5 に示すように進行方向に対し てロボットの手先がツール先端の後方に置かれた場合， 摩擦力の動きによってねじりモーメントが生じる.こ のため, 柔軟ツール自身のねじり回転が発生し、ツー ル先端の位置を制御することはできない，したがって, ねじりモーメントが発生する原因は，押す力と摩擦力 の方向が逆であるためと考えられる.

本論文では，ツール自身のねじり回転を回避するた め, 進行方向においてロボットの手先がツール先端を 押しながら進めるのではなく，図6に示すようにロボ ットの手先がツール先端の前方に置か水てツール先端 を引いて進めることにする. このため, 本論文でロボ ットの手先が進行方向に対してツール先端の前方に常 に置かれるようにしなければならない! したがって, 式(10)に示すロボット手先の目標奖勢を

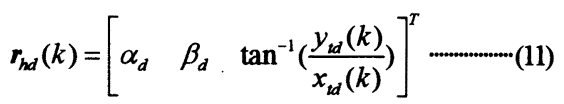

とする.

式(7), (11)を合わせることによってロボット手先 の目標位置・姿势 $\boldsymbol{p}_{r d}(k) \in R^{6 \times 1}$ は

$$
\boldsymbol{p}_{r d}(k)=\boldsymbol{S}_{p} \cdot \boldsymbol{p}_{h d}(k)+\boldsymbol{S}_{r} \cdot \boldsymbol{r}_{h d}(k)
$$

により生成される. ただし，選択行列 $\boldsymbol{S}_{p}, \boldsymbol{S}_{r}$ は

$$
S_{p}=\left[\begin{array}{lll}
1 & 0 & 0 \\
0 & 1 & 0 \\
0 & 0 & 1 \\
0 & 0 & 0 \\
0 & 0 & 0 \\
0 & 0 & 0
\end{array}\right], \quad S_{r}=\left[\begin{array}{lll}
0 & 0 & 0 \\
0 & 0 & 0 \\
0 & 0 & 0 \\
1 & 0 & 0 \\
0 & 1 & 0 \\
0 & 0 & 1
\end{array}\right]
$$

である。

4.3 目摆力の生成 図 1 に示すなぞる作業では, 押し付け力を大きくすると, ツール先端に加える摩擦 力も大きくなり，図 5 に示すように進行中にツール先 端のねじり回転溌生しやすくなる. 本論文では，こ れを避けるためツール先端を $z$ 軸方向に一定の力で作 業面に押し付けるように設定する. すなわち， $z$ 軸方 向での目標力 $f_{2 t}$ を一定にする. また, $z$ 軸方向におけ る位置制御の目標值 $z_{d}$ を 0 とする.

\section{5. 位置とカのハイブリッド制御}

柔軟ツールの先端を与えられた二次元曲線軌道に一 定の力でなぞらせる作業を遂行するため, $z$ 軸方向に 力覚センサを用いて押し付け力を制御し， $x, y$ 軸方向 に視覚情報によって位置制御を行う。しかしながら， 
ツールの変形や手先の摩擦などの影響要因があるため, 単に PID 制御を用いて位置の追徒祦差を减少すること は難しい，そこで本論文では，追従精度を向上させる ため, $x, y$ 軸方向における位置制御にオンライン学習 型ニューラルネットワーク（以下， NNと呼ぶ）を用 いる.

$5 \cdot 1$ ニュ一ラルネットワーつの檴成 本論文で提案 するNNの構成を図 7 に示寸. $x, y$ 軸方向における口 ボットの位置制御に対して，それぞれのサブニューラ ルネットワークを構成する必要がある.

図 7に示すサブニューラルネットワーク $\mathrm{N}_{x} へ$ への 力は, $x$ 軸方向における時刻 $t=k T$ でのロボット手先 の目標位置 $x_{r d}(k)$, 手先の目標速度 $\dot{x}_{r d}(k)$, 手先の 目標加速度 $\ddot{x}_{r d}(k)$ であり, 学習するための修正量は 手先の追従誤差 $\Delta x_{r}(k)$ とする. $\mathrm{NN}_{x}$ と同様に, サブ

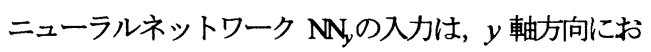
ける時刻 $t=k T$ でのロボット手先の目標位置 $y_{r d}(k)$, 手先の目標速度 $\dot{y}_{r d}(k)$, 手先の目標加速度 $\ddot{y}_{r d}(k)$ で
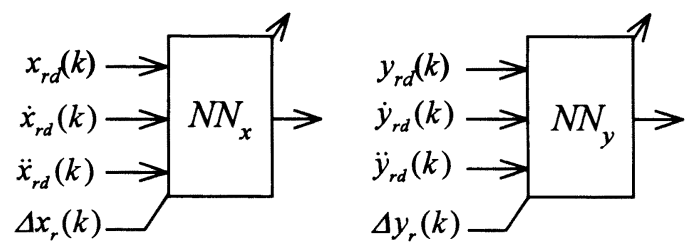

Fig. 7 Architecture of the sub-neural networks

あり，学習するための修正量は手先の追従誤差 $\Delta y_{r}(k)$ とする.

$5 \cdot 2$ ニューラルネットワーのの学習 図7に示すサブ ニューラルネットワーク $\mathrm{N}_{x}$ と $\mathrm{NN}_{y}$ は 3 層型 $\mathrm{NN}$ とす る. 入力層を $\mathrm{A}$, 中間層を $\mathrm{B}$, 出力層を $\mathrm{C}$ とし, 各層 のニューロン数を $N_{A}, N_{B}, N_{C}$ とする. また, 学習に用 いるシグモイド関数 $F(x)$ は

$$
F(x)=\frac{1-e^{-\frac{x}{\mu}}}{1+e^{-\frac{x}{\mu}}}
$$

で表される. ただし， $\mu$ はアニーリングパラメータで ある. 結合荷重の学習は誤差逆伝ぱ法により行わ れる(11).

$5 \cdot 3$ オンライン学習型ニューラルネットワーつを用いた ハイブリット制御ＮNのオンライン学習を用いるこ とによってフィードフォワード制御を実現し，繰り返 し作業を行う場合追従精度を向上できることが知られ ている(12). 本論文では, NNのオンライン学習を用い て位置と力のハイブリッド制御を行うという手法を提 案する. その制御ブロック線図を図8に示す。

図8において

選択行列 $S_{2}=\left[\begin{array}{llllll}1 & 0 & 0 & 0 & 0 & 0 \\ 0 & 1 & 0 & 0 & 0 & 0\end{array}\right]$, 選択ベクトル $s_{f}=\left[\begin{array}{llllll}0 & 0 & 1 & 0 & 0 & 0\end{array}\right]^{T}$ ， 位置・姿勢制御ループの PD コントローラ

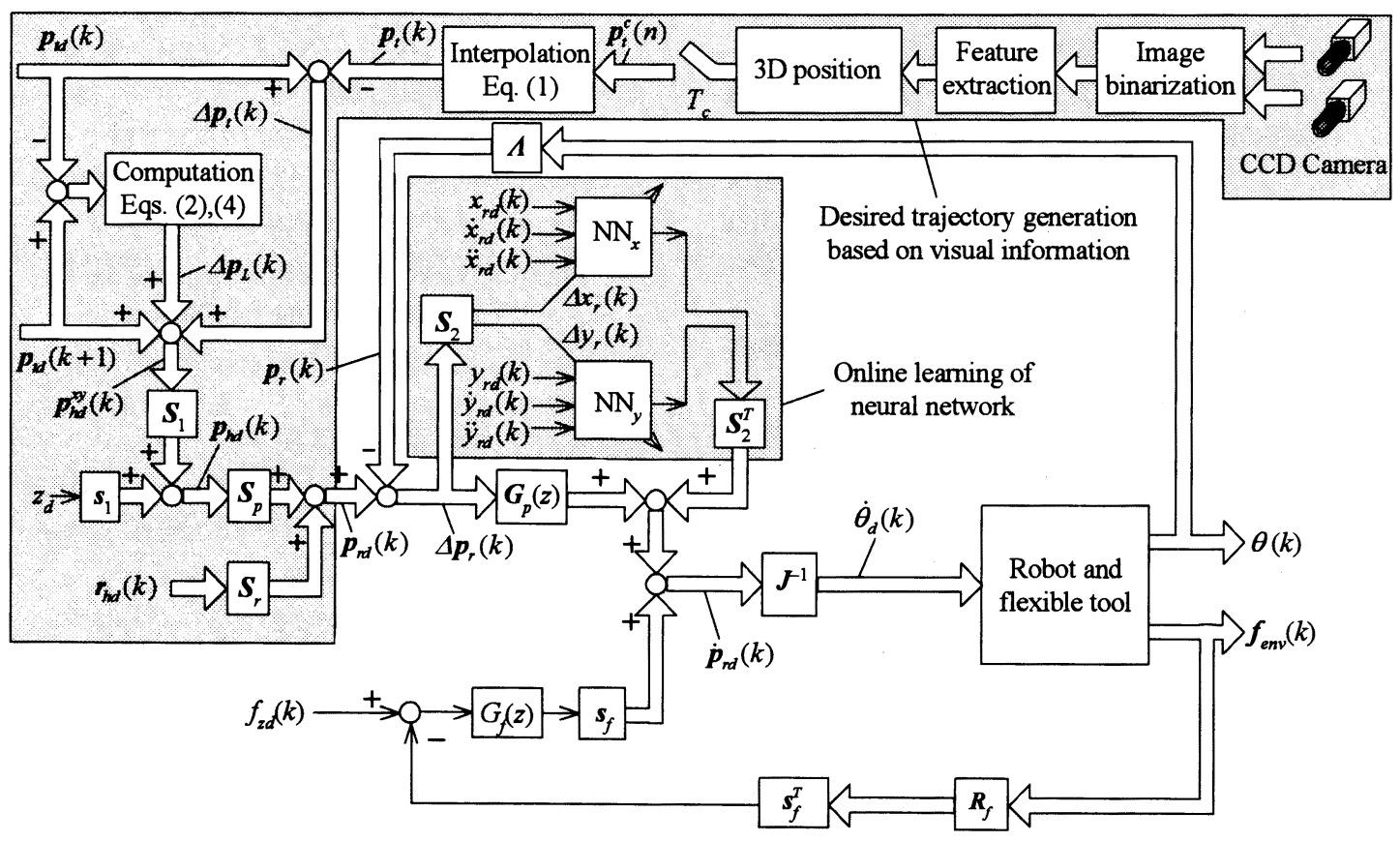

Fig. 8 The proposed position/force hybrid control issue with an online learning neural network 


$$
\begin{gathered}
\boldsymbol{G}_{p}(z)=\boldsymbol{K}_{p}^{p}+\boldsymbol{K}_{I}^{p} \frac{z}{z-1}+\boldsymbol{K}_{D}^{p}\left(1-z^{-1}\right), \\
\text { 力制御ループの } \mathrm{PD} \text { コントローラ } \\
G_{f}(z)=K_{P}^{f}+K_{I}^{f} \frac{z}{z-1}+K_{D}^{f}\left(1-z^{-1}\right),
\end{gathered}
$$

とする.

図 8 では, 時刻 $t=k T$ において GENESSS の画像処理 によってツールの先端位置 $\boldsymbol{p}_{t}^{c}(n-1)$ を検出し, 式(1) により補間を行い, $p_{t}(k)$ を得る. ついで，式(2)〜 (4)から $x-y$ 平面における直線 $L_{0}$ の投影ベクトル $\Delta p_{L}(k)$ を算出したのち, 式(7)よりロボットの目標 位置 $\boldsymbol{p}_{h d}(k)$ を生成する. また, 式(12)のようにロボ ット手先の目標位置・姿勢の 6 自由度ベクトル $\boldsymbol{p}_{r d}(k)$ を算出する. 得られた $\boldsymbol{p}_{r d}(k)$ と, ロボットの運動学 $\boldsymbol{\Lambda}$ によって求められたロボット手先の現在位置 $\boldsymbol{p}_{r}(k)$ $\in R^{6 \times 1}$ との差 $\Delta p_{r}(k)$ を計算し, $S_{2} \cdot \Delta p_{r}(k)$ から $x y$ 軸方 向の位置偏差 $\Delta x_{r}(k), \Delta y_{r}(k)$ を求めてサブニュー ラルネットワーク $\mathrm{NN}_{\infty} \mathrm{NN}_{y}$ の修正量として用いる.

また, P I Dコントローラ $G_{p}(z), G_{f}(z)$ によってロ ボット手先の目標速度 $\dot{\boldsymbol{p}}_{r d}(k)$ を算出する. 逆ヤコビ 行列 $\boldsymbol{J}^{-1}$ を用いてロボットの各関節の目標角速度 $\dot{\boldsymbol{\theta}}_{r}(k)$ を算出し, ロボットのサーボドライブユニット に入力させ，ロボットを制御する．また，図 1 に示す アームを制御するコンピュータでは, 制御サンプリン グ周期 $T$ (=5ms)の間にニューラルネットワークの学習 を4回行うことが可能である.

\section{6. 实 験}

6.1 ねじりモーメントによるツール先端の位罸追 従誤差の影蔀を確認する突験（姿势制御なし，NNな し）実験で与えられたロボット手先の目標軌道 $p_{r d}$ は図 9 に示すような半径 $R=100 \mathrm{~mm}$ の円軌道である. 摩擦力によって引き起こされたねじりモ一メントがツ ール先端の追従精度に与える影響を確認するため, 口 ボット手先の姿勢を固定し，ロボット手先の位置制御 を行う.この場合, 岡体ツールを用いたときと同じよ うに, ツールの長さをロボットの運動学で考慮するこ とによってツール先端の目標軌道 $\boldsymbol{p}_{\boldsymbol{k}}$ を算出する. ま た，2台のカメラを用いて観測したツール先端の実際 位置 $\boldsymbol{p}_{\boldsymbol{t}}$ と算出したツール先端の目標軌道 $\boldsymbol{p}_{t d}$ との誤差 を計算し，ツール先端の追従効果を以下に検討する.

この実験で用いた制御手法は，図 8 の制御ブロック 線図から，(1)視覚情報による目標軌道の生成，(2)NN 学習の部分を除いたブロック線図で表される.この実 験で用いた各パラメータを表 1 に示す.

得られたロボット手先とツール先端の追従軌跡を図
Table 1 Control parameters used in the experiment

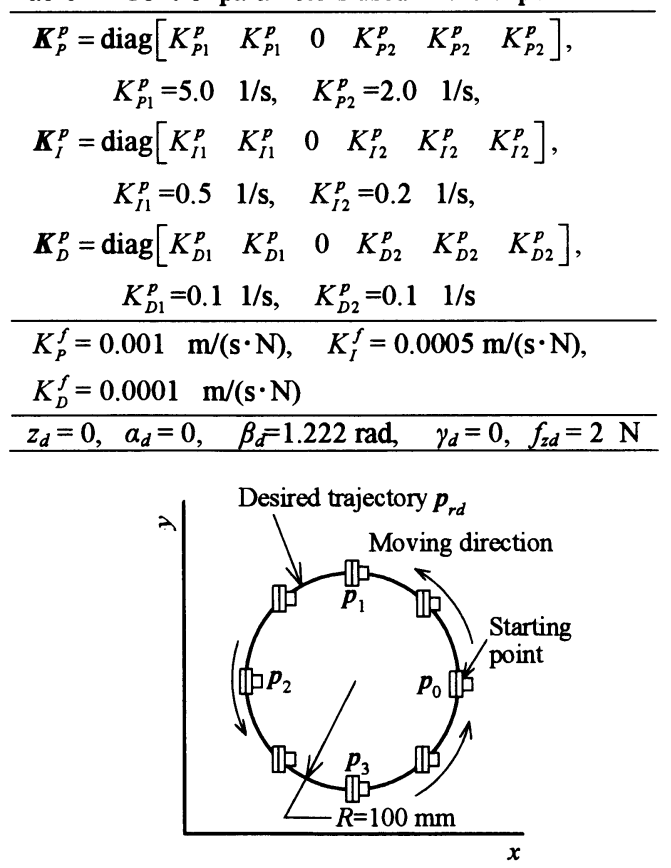

Fig.9 A circle trajectory in $x-y$ plane

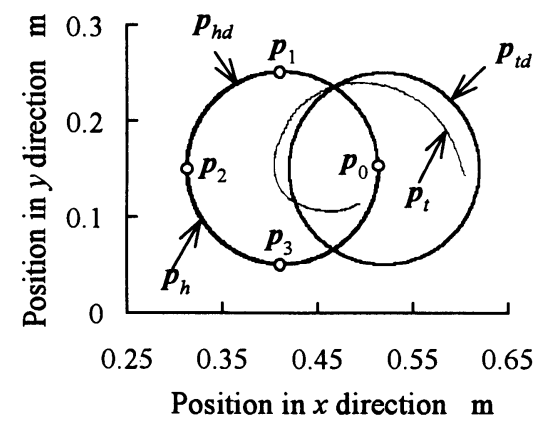

Fig.10 Tracking results in $x-y$ plane of the robot hand and the flexible tool

10 に示す. $x-y$ 平面におけるロボット手先の位置 $p_{h}$ が目標軌道 $\boldsymbol{p}_{h d}$ に追従したが，ツール先端の位置誤差 が大きいことが図 10から分かる.

スタート時点 $t=0$ において柔軟ツールの先端を作業 台に押し付けていることによってツール自身の変形が 生じるため, ツール先端の位置 $\boldsymbol{p}_{t}$ が目標軌道 $\boldsymbol{p}_{t d}$ から 外れる. また， ロボットの手先が点 $p_{0} \rightarrow p_{1} \rightarrow p_{2}$ に沿つ て移動しているとき，進行方向にツール先端の先方に 置か氺たため, ツールを押し付けながら引くことがで きた.これに対して，ロボットの手先が点 $\boldsymbol{p}_{2} \rightarrow \boldsymbol{p}_{3} \rightarrow \boldsymbol{p}_{0}$ に沿って移動しているとき， ロボットの手先は進行方 向にツール先端の後方に置か冯るため, ツールを押し 
付けて進める姿势になる. この場合, 摩擦力によって ねじりモーメントが生じる.このねじりモーメントに よってツール自身を回転させたため，作業の後半にお いてツール先端 $\boldsymbol{p}_{t}$ は目標軌道 $\boldsymbol{p}_{\boldsymbol{t}}$ から大きく外れ，進 行方向に進めることがほとんどできなかったと考えら れる.

\section{2 ツールの先端を目相軌道になぞらせる実験} （NNなし）図5に示寸ツール先端の摩擦による 柔軟ツール自身のねじり回転を避けるため, 図 6 に示 すようにロボットの手先を進行方向において常にツー ル先端の先方に置く必要がある. しかしながら，この 考え方を図 9 に示すような円軌道に適用すると， ロボ ット手先が $z$ 軸回り $360^{\circ}$ 回転させる必要があるが， 、 ニピュレータの構造上から実現することは困難である. このため, 図 11 に示す正弦波状曲線をツール先端の 目標軌道とする. この実験に用いる制御手法は, 図 8 の制御ブロック線図からNNのオンライン学習の部分 を除いたブロック線図で表される. また, 各パラメー 夕の設定を表 2 に示す.

実験で得られた柔軟ツール先端の位置 $\boldsymbol{p}_{\boldsymbol{t}}$ とロボッ トハンドの位置 $p_{h}$ を図 12に示す. 図12では, 進行方 向に合わせてロボットの手先を $z$ 軸の回りに回転させ たため, ねじりモーメントによるツール自身の回転と いう現象がなくなり, ツール先端に与えられた目標軌 道 $\boldsymbol{p}_{\boldsymbol{t} \text { d }}$ をなぞらせるという作業をほほ遂行した. 進行 方向においてツール先端の先方にロボットハンドを置 くという制御手法の有效性は, 図 12 に示寸結果によ り確かめられた。

一方，ロボット手先の姿勢を制御することによって ツール先端 $\boldsymbol{p}_{\boldsymbol{t}}$ が目標軌道 $\boldsymbol{p}_{\boldsymbol{d}}$ に追従しているが，追従 誤差は大きいといらことが図 12から分かる. 図 12 に 示すように， $p_{t}$ の矢印が指す部分において $x, y$ 軸方向 にそれぞれ約 $8 \mathrm{~mm}, 12 \mathrm{~mm}$ の追徒誤差があった.

6.3 ニューラルネットワークのオンライン学習を 用いた追従実検 $x-y$ 平面におけるツール先端の位 置追従精度をさらに向上させるため, 図8 に提案した オンライン学習型NNを用いた制御手法を用いて追従 実験を行った. 6·2節の実験と同様に図 11 に示方軌道 をツール先端の目標軌道とする.このときの制御゚゚ラ メータを表2に, NNのパラメータを表3に示寸.

NNの結合荷重には, 初回の作業の学習開始時点で 乱数を与え，作業が終了したとき結合荷重のデータを ファイルに保存する. 2 回め以降の作業では，毎回作 業が開始するとき前回に保存された結合荷重をファイ ルから読み込み，作業が終了するとき結合荷重の学習 結果をファイルに保存する. このようにして学習の結

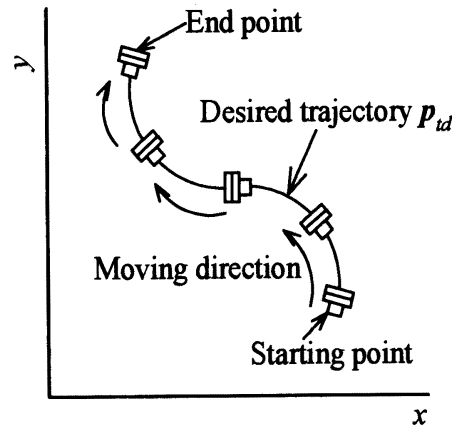

Fig.11 Desired trajectory of the flexible tool's tip

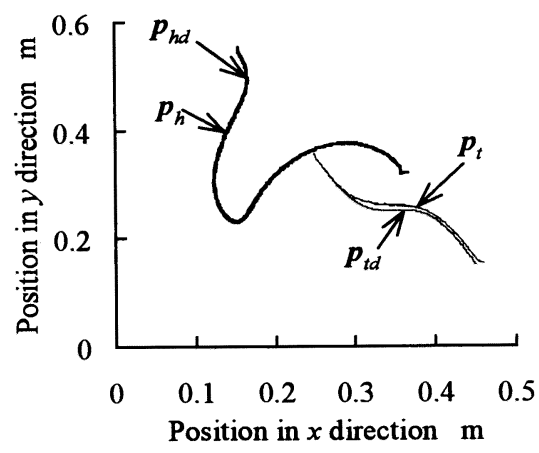

Fig.12 Tracking results in $x-y$ plane of the robot hand and the flexible tool's tip

Table 2 Control parameters used in the experiment

$$
\begin{aligned}
& \boldsymbol{K}_{P}^{p}=\operatorname{diag}\left[\begin{array}{llllll}
K_{P 1}^{p} & K_{P 1}^{p} & 0 & K_{P 2}^{p} & K_{P 2}^{p} & K_{P 2}^{p}
\end{array}\right], \\
& K_{P 1}^{p}=5.0 \quad 1 / \mathrm{s}, \quad K_{P 2}^{p}=2.0 \quad 1 / \mathrm{s} \text {, } \\
& \boldsymbol{K}_{I}^{p}=\operatorname{diag}\left[\begin{array}{llllll}
K_{I 1}^{p} & K_{I 1}^{p} & 0 & K_{I 2}^{p} & K_{I 2}^{p} & K_{I 2}^{p}
\end{array}\right], \\
& K_{I 1}^{p}=0.5 \quad 1 / \mathrm{s}, \quad K_{I 2}^{p}=0.2 \quad 1 / \mathrm{s}, \\
& \boldsymbol{K}_{D}^{p}=\operatorname{diag}\left[\begin{array}{llllll}
K_{D 1}^{p} & K_{D 1}^{p} & 0 & K_{D 2}^{p} & K_{D 2}^{p} & K_{D 2}^{p}
\end{array}\right], \\
& K_{D 1}^{p}=0.1 \quad 1 / \mathrm{s}, \quad K_{D 2}^{p}=0.11 / \mathrm{s} \\
& K_{P}^{f}=0.0010 \mathrm{~m} /(\mathrm{s} \cdot \mathrm{N}), \quad K_{I}^{f}=0.0005 \mathrm{~m} /(\mathrm{s} \cdot \mathrm{N}) \text {, } \\
& K_{D}^{f}=0.0001 \mathrm{~m} /(\mathrm{s} \cdot \mathrm{N}) \\
& z_{d}=0, \quad a_{d}=0, \quad \beta_{d}=1.047 \mathrm{rad}, \quad f_{z d}=0.5 \mathrm{~N}
\end{aligned}
$$

Table 3 Parameters of neural network learning

\begin{tabular}{l|c}
\hline Neuron number of the input layer $N_{a}$ & 3 \\
\hline Neuron number of the hidden layer $N_{b}$ & 6 \\
\hline Neuron number of the output layer $N_{c}$ & 1 \\
\hline Annealing rate $\mu$ & 1.0 \\
\hline Learning rate $\eta$ & 0.85 \\
\hline
\end{tabular}


果を蓄積することができ，繰り返し作業が進むにつれ て追従精度が向上することを期待できる.

NNの学習に用いる誤差修正信号を図 13 に示す.

一般に, 学習誤差が収束するまで一定の学習回数が必 要とされる(12).この実験の場合, 1 回めの作業開始の 時点において $x$ - $y$ 軸方向の位置制御は主に PID 制御で あり，位置追従毁差は大きいが，約 10000 回の学習 が終了してから追従鼠差は徐々に収束していることが 図13から分かる.1回めの実験で得られた結合荷重を

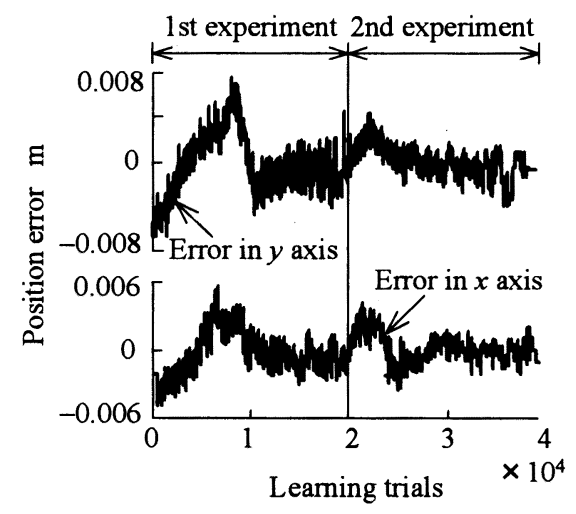

Fig.13 Error signals for learning

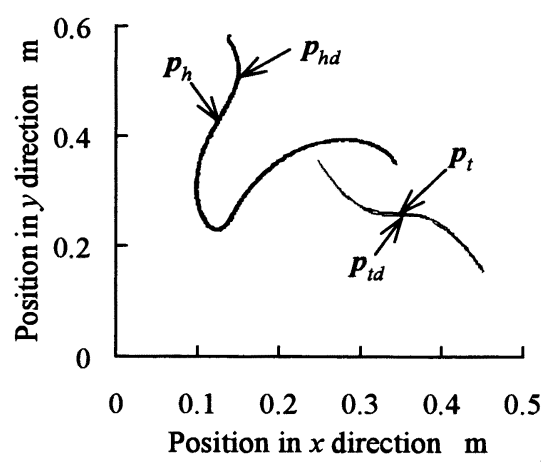

Fig.14 Tracking results in $x-y$ plane of the robot hand and the flexible tool's tip

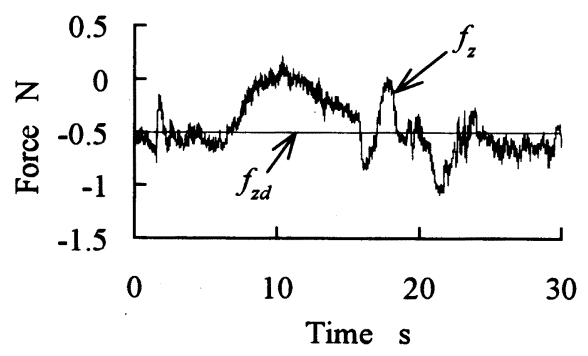

Fig.15 Results of force control in $z$ axis
2 回めの実験に用いたため, 追従䛠差はより速く减少 し，追従精度は向上した.

2 回めの実験で得られた $x-y$ 平面の追従軌跡を図 14 に, $z$ 軸方向の力を図 15 に示す. 図 12 の追従軌跡と 比べると，オンライン学習型NNを用いた実験におい て追従誤差を大幅に减少したことが図 14 から分かる. 特に図 14 では, $p_{t}$ の矢印が指寸部分において $x, y$ 軸方 向の追彷鼠差の最大值は約 $4 \mathrm{~mm}$ であり，6.2 節での 実験で得られた追従誤差の半分以下である. また, $z$ 軸方向での力は目標値 $0.5 \mathrm{~N}$ の付近で変動したことが 図 15 により分かる. 提案した手法を用いて柔軟ツー ルの先端を目標軌道になぞらせる実験を遂行したこと によってその有効性を実証した.

\section{7. 結 論}

本研究で得られた主な結果は次のとおりである.

(1) ニューラルネットワークのオンライン学習を 用いてマニピュレータがもつ柔軟ツールの先端の位置 と力のハイブリッド制御を行うという手法を提案し, 柔軟ツールの先端に曲線軌道をなぞらせる実験を行い， 本手法の有効性を実証した。

（2）本論文で提案した手法は，視覚情報を用いる ため, 柔軟ツールの変形モデルを立てることが困難な 場合に適用できるという利点をもつ. 実験によって本 手法の有効性を確かめた.

\section{文献}

(1) 平井慎一, 日本ロボット学会誌, 16-2(1998), 136-139.

（2）中垣博文，日本ロボット学会誌，16-2(1998), 159-162.

(3) 平井慎一・野口英昭, 日本ロボット学会誌, 158 (1997), 1172-1179.

（4）中垣博文 - 北垣高成・小笠原司・築根秀男, 日本ロボ ット学会誌, 15-3(1997),422-430.

（5）若松栄史・和田隆広，日本ロボット学会誌，16-2 (1998), 145-148.

（6）吳建青 · 羅志偉 - 山北昌毅 - 伊藤宏司，機論，63607， C(1997), 937-944.

（7）小野栄一，日本ロボット学会誌，16-2(1998), 149-153

(8) 久田俊明, 日本ロボット学会誌, 16-2 (1998), 140-144.

(9) Chen, C. Y. and Zheng,Y. F. , J. Robotic System, 9-5 (1992), 595-612.

（10）黄 健 - 藤堂勇雄, 機論, 67-660, C(2001)，2616-1623.

(11) Cichocki, A and Unbehauren, R, Newal Networks for Optimization and Signal Processing, (1993), 122-135, John Wiley \& Sans.

（12）劉明輝 - 藤堂勇雄, 機論, 57-539, C(1991)，2256-2262. 